\title{
TOWARDS AN EFFECTIVE CATTLE GRAZING AND REARING LEGAL FRAMEWORK: AN IMPERATIVE FOR ENVIRONMENTAL PROTECTION
}

\author{
Tolulope Ogboru* \\ Oluwatoyin Adejonwo-Osho**
}

\begin{abstract}
When scholars write about environmental degradation in their publications, they hardly mention cattle grazing and rearing as one of its causes. Nevertheless, this activity, which has impacted the environment adversely, is a direct cause of land degradation, threatens the resources and ecosystem's services that biodiversity provides, and is a threat to the Sustainable Development Goals (SDGs), particularly SDG 15 . Livestock pastoralism has intensified in Nigeria in recent times, leading to greater environmental concerns and conflicts over access to natural resources. A close scrutiny of Nigeria's municipal laws shows the absence of any statute that provides for the protection of the environment from this economic activity except the recent anti-open grazing laws enacted by some states. This seems to account for the unsustainable management of cattle grazing lands among other factors. The recent conflicts, killings and destruction of properties between herdsmen and farmers in Nigeria is one of the consequences of ineffective management of access to natural resources (land) and an ineffective regulatory framework for addressing the environmental degradation resulting from unregulated grazing, which are both exacerbated by climate change. An effective cattle grazing legal framework, it is argued, is imperative to complement existing environmental laws in addressing the environmental challenges occasioned by cattle grazing and ongoing tensions.
\end{abstract}

Key words: Nomadic Pastoralism, Pastoralist, Transhumance, Ranching, Grazing Reserve

DOI: https://dx.doi.org/10.4314/jsdlp.v9i1.4

* PhD, Lecturer, Faculty of Law, University of Jos, Nigeria. Email address: ogboruit@yahoo.com.

$* *$ PhD, Lecturer, Faculty of Law, University of Lagos, Nigeria. Email address: oadejonwoosho@yahoo.com. 


\section{INTRODUCTION}

Land is a natural resource which should be managed sustainably. ${ }^{1,2}$ In sub-Saharan Africa, land is central to economic and social development. ${ }^{3}$ In the 20th century, most countries experienced rapid population growth, slow economic development and environmental degradation. In the process, many parts of Africa changed from being land abundant to being land scarce. Studies estimate that Africa is losing an estimated 37 million hectares of forest and woodlands each year. ${ }^{4}$ The United Nations Environment Programme (UNEP) estimates that Africa is losing more than a quarter of its arable land due to degradation. ${ }^{5}$ The causes of degradation have been attributed to deforestation, population pressure, agriculture, overgrazing, uncontrolled logging, fuel-wood and wildfire. ${ }^{6}$

A recent report on natural resources, the environment, and conflict has the following to say:

[A] large proportion of Africans are dependent on natural resources and the environment to subsist. The natural environment is the foundation of livelihoods based on subsistence and commercial farming etc.... These activities are inextricably linked to the

1 Food and Agriculture Organization of the United Nations, "The Approach Facing the Challenge" < http://www.fao.org/docrep/004/x3810e/ x3810e04.htm $>$ accessed 2 April 2018.

2 ibid.

3 ibid.

4 Samuel C Nana-Sinkam, "Land and environmental degradation and desertification in Africa" (Food and Agriculture Organization of the United Nations, 1995) < http://www.fao.org/docrep/x5318e/x5318e00.htm> accessed 2 April 2018.

5 United Nations Environment Programme, "Africa: Atlas of our Changing Environment" (UNEP, 2008) < http://wedocs.unep.org/bitstream/handle/ 20.500.11822/7717/817.pdf? sequence $=3 \&$ isAllowed $=\mathrm{y}>$ accessed 2 April 2018. (UNEP 2008)

6 UNEP 2008. See also Godfrey C. Kipsisei, "Environmental Degradation and Social Conflict in Trans Mara District, South Rift valley of Kenya" (MA Thesis, University of Nairobi 2011) < http://erepository.uonbi.ac.ke/bitstream/handle/ 11295/4483/Kipsisei_Environmental\%20degradation\%20and\%20social\%20 conflict.pdf? sequence $=1>$ accessed 2 April 2018. See also Godwin Arku and Paul Mkandawire, "Precarious Balance: The Future of Environmental Degradation in Sub-Saharan Africa" in Isaac N Luginaah and Ernet K Yanful (eds) Environment and Health in Sub-Saharan Africa: Managing an Emerging Crisis (Springer 2009). 
availability of natural resources and the sustainable management of those resources, and in turn, the allocation, management and exploitation of increasingly limited natural resources can contribute to conflict in Africa. ${ }^{7}$

Lack of access to natural resources (land), upon which humanity depends, will lead to environmental degradation, competing interest and conflict, loss of lives and properties. ${ }^{8}$ Violent conflicts between nomadic herdsmen and sedentary agrarian communities are not new due to competing interest over access to natural resources such as land and water (for grazing their cattle). However, in recent times, there have been increased reports of frequent clashes between herdsmen and farmers in different farming communities in Nigeria, raising issues of lack of access, ${ }^{9}$ unsustainable use and management of natural resources, lack of a legal and regulatory framework, resulting in environmental degradation and exacerbating the insecurity and food crisis particularly in rural communities in Nigeria. Sometime in January 2018, it was reported that herdsmen burnt five hectares of oil palm plantation including yam and cassava plantations at Ilado village in the Akure South Local Government Area of Ondo State. ${ }^{10}$ The farmer reported that the main reason the herdsmen burnt his farm was to burn off the dried vegetation in order for fresh grass to spring up days later for their cattle to feed on and that the nomadic pastoralists had

7 Alida Kok and others, "Natural Resources, The Environment and Conflict" (African Center for the Constructive Resolution of Disputes, 19 November 2009) $<$ http://www.accord.org.za/publication/natural-resources-the-environmentand-conflict/> accessed 2 April 2018.

8 See the following: ibid; Piers Blaikie, "Environment and Access to Resources in Africa" (1989) 59 Journal of the International African Institute 18; Kipsisei (n $6)$. On the theory of access see the following: Jesse C. Ribot and Nancy Lee Peluso, "A Theory of Access" (2003) 68 Rural Sociology 63.

9 Access to land can be described as the opportunity for temporary or permanent use and occupation of land for purposes of shelter, productive activity, or the enjoyment of recreation and rest. Access to land also entails the access to other resources (both natural and non-natural) annexed to land such as water.

10 Peter Dada, "Fulani Herdsmen Set Falae's Five-Hectare Oil Palm Plantation Ablaze" Punch (Akure, 21 January 2018) < http://punchng.com/breakingfulani-herdsmen-set-olu-falaes-farm-ablaze/> accessed 19 June 2018. See also Sahara Reporters, "Suspected Fulani Herdsmen Set Ablaze Olu Falae's Farm in Ondo" Sahara Reporters (New York, 21 January 2018) <http:// saharareporters.com/2018/01/21/suspected-fulani-herdsmen-set-ablaze-olufalaes-farm-ondo > accessed 19 June 2018. 
been engaged in this practice on his farm for the last three years. ${ }^{11}$ These attacks invariably also leads to retaliatory attacks on the pastoralist community by the host communities. Incidents like the above have been reported in all regions of the country. ${ }^{12}$ Limitation of space will not permit a catalogue of recent clashes between pastoralist and local farming communities in Nigeria.

These incidents bring to the fore the several ways by which nomadic pastoralism can cause degradation of the environment. Indeed, bush burning is one of the environmentally destructive acts the nomadic pastoralists practice in Nigeria as it contributes to air pollution. They burn farmlands in order to cause vegetation re-growth within a short time for their cattle to feed on. In addition, the farmer revealed in an interview, that prior to the time this incident took place, the nomadic herdsmen used to lead their cattle to drink water in the dam on his farm and there would be signs that they had been there because animal waste would be seen in and around the water. This is another form of environmental degradation - water pollution. The Vice-President of Nigeria also lent credence to this when he said that the issues of scarcity of resources is at the heart of the conflicts between farmers and herdsmen in the country, that there is increasing competition for grazing land and water. ${ }^{13}$ Describing the herding system in Nigeria, Bello said: “...During migration, a typical herd consisting of several family units

11 Temitope Olanipekun, "Why Fulani Herdsmen Burnt My Farm - Falae" Daily Post (Nigeria, 22 January 2018) < http://dailypost.ng/2018/01/22/fulaniherdsmen-burnt-farm-falae/> accessed 19 June 2018.

12 The incessant conflict between Fulani herdsmen and farmers in the Ikole and Oke Ado Ekiti State which prompted the Ekiti State government to enact the Anti-grazing law in Ekiti State. In 2017, it was reported that herdsmen attacked Dong and Lawaru villages in Adamawa State in the Northern Part of the country and that lives and properties were destroyed. Don Silas, "Suspected herdsmen attack villages in Adamawa" Daily Post (Nigeria, 10 December 2017) <http://dailypost.ng/2017/12/04/breaking-suspected-herdsmen-attackvillages-adamawa $>$ accessed 6 April 2018.

13 The UN secretary-general Antonio Guterres was quoted as saying that "Most of today's conflicts....are fueled by competition for power and resources, inequality, marginalization and exclusion, poor governance, weak institutions, sectarian divides". See Nidhi Sharma, "One Fourth of Armed Conflicts in ethnically divided Countries Coincide with Climate Problems: Study" The Economic Times (20 May 2017) <https://economictimes.indiatimes.com/ news/politics-and-nation/one-fourth-of-armed-conflicts-in-ethnically-dividedcountries-coincide-with-climatic-problems-study/articleshow/ 58757224.cms > accessed 19 June 2019. 
move in a column of up to five meters wide and two kilometres long. And by the time it passes any given point, 'everything that stands at that point is destroyed"'. ${ }^{14}$

Unregulated nomadic grazing, apart from its potential to increase insecurity and conflicts, also has an adverse impact on the environment. Over grazing causes severe damage to the environment such as the exposure of fragile soils leading to severe erosion and subsequent downstream siltation, and the introduction of aggressive weeds by the cattle. ${ }^{15}$ Environmental degradation contributes to scarcity of natural resources such as land, water, and vegetation, all of which can result in more conflict. ${ }^{16}$ Such conflicts will arise as a result of competing interests for natural resources and more conflicts will lead to increased environmental degradation; it thus becomes a vicious cycle. ${ }^{17}$

In view of the negative environmental impacts of nomadic pastoralism, the need for environmental considerations in its legal framework cannot be overemphasized. Unfortunately, the spotlight in policy documents, scholarly articles and in government circles has been more on the impact of nomadic grazing on other socio-economic factors and not on the environment. ${ }^{18}$ Past and present attempts at regulating cattle grazing appear to be ineffective in Nigeria. This article is divided

14 Alhassan Usman Bello, "Herdsmen and Farmers Conflicts in North-Eastern Nigeria: Causes, Repercussions and Resolutions" (2013) 2 Academic Journal of Interdisciplinary Studies 129, 131. See also Ismail Iro, "Grazing Reserve Development: A Panacea to the Intractable Strife between Farmers and Herders", (Gamji, 1994) <http://www.gamji.com/fulani8.htm> accessed 2 April 2018.

15 See the following: Charles L.A. Asadu and others, "Cattle grazing and environment in eastern Nigeria: impact on soil physical properties" (1999) 28(2) Outlook on Agriculture 103; Iain Fraser and Tony Chisholm, "Conservation or cultural heritage? Cattle grazing in the Victoria Alpine National Park” (2000) 33 Ecological Economics 63, 67.

16 Carl Christiansson and Eva Tobission, "Environmental Degradation as a Consequence of Socio-Political Conflict in Eastern Mara Region, Tanzania" in Anders Hjort af Ornäs and MA Mohamed Salih (eds) Ecology and Politics: Environmental Stress and Security (Scandinavian Institute of African Studies 1989) 60.

17 See Anders Hjort af Ornas, "Environment and Security of Dryland Herders in Eastern Africa" in Anders Hjort af Ornäs and MA Mohamed Salih (eds) Ecology and Politics: Environmental Stress and Security (Scandinavian Institute of African Studies 1989) 8.

18 Ajah Julius, "Small-scale Farmer's Perception on the Impact of Grazing Livestock Animals on Crop Production in Abuja, Nigeria" (2012) 5 Trends in Agricultural Economics 115. 
into six sections. After this introduction, section 2 highlights the history and features of cattle grazing and rearing in Nigeria; section 3 examines the environmental impacts of unregulated nomadic cattle rearing and grazing in Nigeria; and section 4 examines the existing legal framework for cattle grazing in Nigeria, it highlights its inadequacies and the ongoing efforts at developing a sustainable legal framework. Section 5 highlights the guiding principles that are crucial for an effective legal and regulatory framework and also enhance effective management, environmental protection and sustainable development. As demonstrated in this article, an effective and enforceable legal framework on cattle grazing could engender a safe and sustainable environment in Nigeria. Section 6 is the conclusion.

\section{SYSTEM OF NOMADIC CATTLE GRAZING AND REARING}

Nomadic cattle grazing and rearing is a major occupation of the people in the Sahel and parts of the Savannah regions of Nigeria. ${ }^{19}$ Pastoralists are people whose major source of livelihoods is livestock herding. ${ }^{20}$ The importance of this industry, particularly its contribution to food production in the developing world, cannot be overemphasized. However, the environmental implications cannot be ignored as well. In Nigeria, migration is part of a comprehensive economic strategy. ${ }^{21}$ The movement of the pastoralists is governed by livelihood norms associated with the needs of their cattle for pasture. ${ }^{22}$ Reportedly,

19 Nigerian Environmental Study/Action Team and Brent Tegler (eds), Climate Change Adaptation Strategy Technical Reports - Nigeria (CCASTR) (Building Nigeria's Response to Climate Change, NEST 2011) $150<$ http://csdevnet.org/ wp-content/uploads/Climate-Change-Adaptation-Technical-Report.pdf > accessed 3 April 2018. (CCASTR).

20 Veena Bhasin, "Pastoralists of Himalayas" (2011) 33 Journal of Human Ecology 147. See also Sidiqat A Aderinoye-Abdulwahab and Lawal L Adefalu, "Pastoral Communities in Nigeria: Another Case of Marginalisation" (56th Australian Agricultural Resource Economic Society annual conference, Fremantle, Western Australia, 7-10 February 2012) <https://ageconsearch.umn.edu/bitstream/ 124218/2/2012AC\%20Aderinoye\%20CP2.pdf> accessed 6 April 2018.

21 CCASTR (n 19).

22 In Nigeria, 90 percent of cattle are owned by the Fulani ethnic group and they constitute the core of traditional pastoralists. This group of people are settled in the arid and semi -arid regions of the country. They however, migrate from one part of the country to another in search of graze land and water for the animals. See the following: Bello (n 14) and Aderinoye-Abdulwahab (n 20). 
livestock production accounts for one third of Nigeria's agricultural GDP, which shows its importance. ${ }^{23}$ According to Cervenka, herds are the main wealth reserve for pastoralists generally, and their livestock are crucial in their socio-economic structure. ${ }^{24}$

In the different countries in Africa, nomadic pastoralists are usually a mix of both the indigenous ones and those who migrated from other neighbouring African countries in search of water and pasture. The latter movement is known as transhumance, even though the movement of the nomadic pastoralists within a country is also regarded as transhumance by some authors. ${ }^{25}$ Transhumance came about as a result of a policy of Economic Community of West Africa (ECOWAS). In furtherance of this policy, ECOWAS developed a Transhumance Protocol, 1998 under Decision A/DEC.5/10/98. ${ }^{26}$ This Protocol was signed by ECOWAS States, including Nigeria. It guarantees the free movement of pastoralists or herders across the sub-region. ${ }^{27}$ This explains why there are foreign herdsmen in Nigeria. No doubt, this plays an important role in West African society by providing livestock and its products as well as revenue from the cattle trade. ${ }^{28}$ However, in recent times, the

23 CCASTR (n 19). The livestock species are cattle, goat, sheep, camel and local poultry.

24 Zdenek Cervenka, "The Relationship Between Armed Conflict and Environmental Degradation in Africa" in Anders Hjort af Ornäs and M.A. Mohamed Salih (eds), Ecology and Politics: Environmental Stress and Security in Africa (Scandinavian Institute of African Studies 1989) 30.

25 See Kwaku Agyemang, "Transhumance Pastoralism in Africa: Thoughts from the Field" in Ndiaga Gueye (ed), Sustainable Pastoralism and Rangelands in Africa, vol 31 (Food and Agriculture Organization of the United Nations 2017) 3. See also Edward Kilawe and Patrick M Bahal'okwibale, "Pastoralism and Rangeland Management in Drylands of Eastern Africa: A Review of Issues, Challenges and Practices" Ndiaga Gueye (ed), Sustainable Pastoralism and Rangelands in Africa, vol 31 (Food and Agriculture Organization of the United Nations 2017) 18.

26 "Decision A/Dec.5/10/98 relating To the Regulation on Transhumance between ECOWAS Member States" (1998) 35 Official Journal of the Economic Community of Western American States < http://ecpf.ecowas.int/wp-content/ uploads/2016/01/Decision-1998-English.pdf $>$ accessed 3 April 2018.

27 Ibid 5. See Article 3 of the Decision which states that "The crossing of land borders for the transhumance of cattle, sheep, goats, camels and donkeys according to conditions defined by this Decision is authorized between all the countries of the community"; See Felix Lankester and Alicia Davis, "Pastoralism and Wildlife: Historical and Current Perspectives in the East African rangelands of Kenya and Tanzania" (2016) 35 Rev Sci Tech 473.

28 The human population gains most of its livelihoods from the animals reared, from meat, milk, butter, cheese and hides. 
practice has resulted in severe conflicts wherever nomadic pastoralists and their herds pass through or attempt to settle temporarily.

Against this background, insecurity and increased conflict occurs, threatening national security, the livelihood of crop farmers and environmental sustainability, not only in Nigeria but also in most countries in Africa and other non-African countries. ${ }^{29}$ Agyemang buttressed this point when he stated that almost all coastal countries in West Africa (Cote D'Ivoire, Ghana, Togo, Benin and Nigeria) with borders with landlocked dry countries with large pastoral herds, have experienced conflicts between host communities and cattle herders from the northern countries, mainly Chad, Niger, Mali, Burkina Faso and northern Cameroun. ${ }^{30}$ Conflicts have been reported to be usually centred on the destruction of crops, pollution of rivers and ponds serving as source of drinking water for communities, indiscriminate bush burning by herders and harassment of nomads by host communities' youths, among other complaints. ${ }^{31}$

A technical report on climate change adaptation strategy for Nigeria noted that Lake Chad's shrinking has increased the influx of longdistance migrant nomadic cattle herders ${ }^{32}$ from the Republic of Niger, as well as the migration of citizens of Chad and Niger further south in search of optimum opportunities. The report noted that these longdistance migrants have been well-armed since the mid-1990s and are willing to use violence to assure their grazing. ${ }^{33}$ This has contributed to the violent conflicts between herders and farmers in the north-eastern

29 David Anaafo, "Contested Pastures: State Land Reform Policies, Community Dynamics and Pastoralism in the Nkoranza South Municipality, Ghana" in Ndiaga Gueye (ed), Sustainable Pastoralism and Rangelands in Africa, vol 31 (Food and Agriculture Organization of the United Nations 2017) 52; See also Agyemang (n 25).

301 Agyemang (n 25) 4; The Nigerian government has stated that most of the herdsmen involved in the violence being witnessed in the country are foreigners from neighbouring countries.

31 See also Albert U Ofuoku and Benjamin I Isiefe, "Causes, Effects and Resolution of Farmers-Nomadic Cattle Herders Conflict in Delta State, Nigeria," (2009) 1 International Journal of Sociology and Anthropology 47; Ibrahim Baidoo, "Farmer-Herder Conflicts: A Case Study of Fulani Herdsmen and Farmers in the Agogo Traditional Area of the Ashanti Region" (MA thesis, University of Ghana 2014) <http://ugspace.ug.edu.gh/handle/123456789/7253> accessed 6 April 2018.

32 Usually refered to as "Udawas".

33 CCASTR (n 19)148. 
part and other regions of Nigeria. Considering the influx of foreign herdsmen into Nigeria, the pressure cattle grazing will engender in the environment is bound to be enormous. ${ }^{34}$

\section{ENVIRONMENTAL IMPACTS OF UNREGULATED CATTLE GRAZING}

The livestock sector contributes significantly to global warming through greenhouse gas (GHG) emissions. ${ }^{35}$ Emissions from livestock accounts for 9 per cent of all carbon dioxide emissions derived from humanrelated activities and 37 per cent of Methane emissions. This is primarily as a result of gas from the digestive system of cattle and other domesticated ruminants. ${ }^{36}$ The United Nation's Food and Agriculture Organization (FAO) and other organizations also highlights the harmful effects of unregulated livestock production on the environment and the fact that they are becoming increasingly serious at all levels - local, regional, national and global. ${ }^{37}$ The environmental impacts range from

34 A statement by the president of the Miyetti Allah Kautal Hore Fulani SocioCutltural Group, Abdullahi Bello Bodejo is instructive on this point. He stated, at a joint news conference with the Miyetti Allah Cattle Breeders Association of Nigeria, that "Anywhere you keep this volume of cows we have now, for two weeks, they will eat out everything and you will have ecological disaster". Abbas Jimoh, "Grazing Laws: Nigerian Cows Unsuitable for Ranching" Daily Trust (Nigeria, 19 November 2017).

35 Petr Havlik and others, "Climate Change Mitigation Through Livestock System Transitions" (2014) 111 Proceedings of the National Academy of Science 3709. See also "Rearing Cattle Produces More Greenhouse Gases than Driving Cars, UN report warns" UN News (29 November 2006) < https://news.un.org/en/ story/2006/11/201222-rearing-cattle-produces-more-greenhouse-gasesdriving-cars-un-report-warns $>$ accessed 20 June 2018. See the full report: Livestock, Environment and Development Initiative, and Food and Agriculture Organization of the United Nations, Livestock's Long Shadow: Environmental Issues and Options (FAO 2006) <http://www.fao.org/docrep/010/a0701e/ a0701e.pdf $>$ accessed 20 June 2018.

36 Petr Havlik and others, "Crop Productivity and the Global Livestock Sector: Implications for Land Use Change and Greenhouse Gas Emissions" (2013) 95 American Journal of Agricultural Economics 442. See also Mercedes MC Bustamante and others, "Climatic Change: Estimating Greenhouse Gas Emissions from Cattle Raising in Brazil" (2012) 115 Climate Change 559.

37 Henning Steinfeld and others (eds), Livestock in a Changing Landscape: Drivers, Consequences and Responses, vol 1 (Island Press 2010). See also Stanford University, "Harmful Environmental Effects of Livestock Production on The Planet "Increasingly Serious", Says Panel" ScienceDaily (22 February 2007) 
land degradation, and air and water pollution, to loss of biodiversity and as with climate change and other modern environment challenges, developing countries are especially vulnerable to the effects of the present nomadic mode of cattle rearing. ${ }^{38}$ According to a recent report, the livestock sector generates more greenhouse gas emissions, as measured in $\mathrm{CO}_{2}$ equivalent (18 per cent more than transport) and it is also a major source of land and water degradation. ${ }^{39}$ The ECOWAS Transhumance Protocol also recognizes that transhumance is a source of health, social, environmental, economic and political problems, despite the fact that the development of livestock breeding is an integral part of any food security. ${ }^{40}$

According to Herrero and Thornton, livestock is the largest land use sector on earth and that many of the solutions to the challenges of food security depend on how sustainably this sector is managed. ${ }^{41}$ Pelletier and Tyedmers argue that the livestock sector will soon reach or exceed recently published sustainability thresholds in some of these environmental problems, including climate change. ${ }^{42}$ This can be worsened by growing demand for agricultural products, especially livestock due to increased prosperity. ${ }^{43}$ Some anticipate that meat

<www.sciencedaily.com/releases/2007/02/07022014524.htm> accessed 20 June 2018. The researchers presented their report at the annual meeting of the American Association of Science in San Francisco: Dilda Karayu, "Land Tenure System in Pastoralist Societies: Findings of a Study tour to Peru" Ndiaga Gueye (ed), Sustainable Pastoralism and Rangelands in Africa, vol 31 (Food and Agriculture Organization of the United Nations 2017) 29.

38 Henning Steinfeld and Pierre Gerber, "Livestock Production and the Global Environment: Consume Less or Produce Better?" (2010) 107 Proceedings of the National Academy of Sciences 18237; Mario Herrero and Philip K Thornton, "Livestock and Global Change: Emerging Issues for Sustainable Food Systems" (2013) 110 Proceedings of the National Academy of Sciences 20878; and Charles LA Asadu and others, "Cattle Grazing and Environment in Eastern Nigeria: Impact on Soil Physical Properties" (1999) 28 Outlook on Agriculture 103.

39 Livestock's Long Shadow: Environmental Issues and Options (n 35). See also Steinfeld (n 37).

40 See the Preamble, (n 26).

41 Herrero (n 38).

42 Nathan Pelletier and Peter Tyedmers, "Forecasting Potential Global Environmental Costs of Livestock Production 2000 - 2050" (2010) 107 Proceedings of the National Academy of Sciences 18371. See also ibid.

43 Steinfeld (n 38). See also Kyle Downey, "How Does Livestock Industry Impact the Environment?" (Law Street, 2 June 2016) <www.lawstreetmedia.com/ issues/energy-and-environment/various-ways-livestock-industry-impactedenvironment> accessed 13 February 2018. 
demand will double by 2020 and that if humans do not manage to reduce global greenhouse gas emissions by that time, then the globally accepted goal of limiting warming to $2^{\circ} \mathrm{C}$ will be extremely difficult to accomplish. ${ }^{44}$ Already, there is warning that Africa is set to experience unprecedented boom in demand for animal foods over the coming decades that if not properly managed could lead to the spread of new diseases, damage the environment and affect people's livelihoods. ${ }^{45}$

Water is said to influence the distribution of pasture land and the distribution of livestock. As a result, large herds of cattle concentrate wherever there is water. ${ }^{46}$ The effect of this is that wells, ponds and streams dry up. This provokes desiccation, drought and water shortage. ${ }^{47}$ Projections of water use show increased pressure on total fresh water resources, notably on blue water (irrigation), and moderate increases in the efficiency of green water use. ${ }^{48}$ Recently, it was reported that the Lake Chad Basin, which forms Nigeria's main source of water supply is drying up. Such concentration around water sources invariably results in the tensions over access to water, pollution due to waste by the cattle and much of the waste gets carried along by run-offs and then dumped inside the streams and rivers. This is in addition to the fact that such wastes will encourage flies and stench which may lead to other public health issues.

Overgrazing has also played a role in degrading scarce natural resources. Overgrazing depletes vegetation and causes deforestation. ${ }^{49}$ Overgrazing is basically caused by a large number of cattle beyond the carrying capacity of an area of land. In Nigeria, Iro states that Borno State has the largest population of livestock in Nigeria but there is hardly enough grass for year-round grazing, and same can be said of most parts of Nigeria. ${ }^{50}$ Iro states further that the nomadic pastoralists adapt to these shortages by using farm residue or by grazing in urban

44 Livestock's Long Shadow: Environmental Issues and Options (n 35).

45 Umberto Bacchi, "Can Africa Deal With an Expected Boom in Demand for Meat?" Reuters (13 March 2017) < https://www.reuters.com/article/us-africa-foodlivestock/can-africa-deal-with-an-expected-boom-in-demand-for-meatidUSKBN16K1V3> accessed 20 June 2018.

46 Onah R Ogri, "Environmnetal Problems Associated with Livestock Production in Tropical Africa" (1998) 19 Environmentalist 137, 141.

47 Ibid.

48 Herrero (n 38).

49 Ogri (n 46) 140.

50 Iro (n 14). 
areas. This has led to the scavenging of food by cows and other animals around school playgrounds, golf courses, residential areas, street shoulders and even airport surroundings. ${ }^{51}$ All of these leads to other problems of traffic flow obstruction, endangerment of street users and urban congestion. ${ }^{52}$

Bush burning is another environmental problem caused by cattle grazing. Bush burning is common in the dry season to improve pasture lands for cattle. Fire has been used extensively in Africa by livestock pastoralists to condition grazing areas. ${ }^{53}$ Apart from the smoke the fire produces, burning reduces vegetative cover for wildlife, and in some cases, excessive burning destroys soil microorganisms which in turn reduces soil fertility. It also destroys wildlife habitat.

A study conducted in the eastern part of Nigeria concluded that if cattle grazing is not controlled, soil properties when exposed would continue to deteriorate, which could lead to extensive soil erosion. ${ }^{54}$ Compaction of the topsoil resulting from the pressure exerted by the hooves of an increased number of cattle per unit area has been shown to negatively impact soil physical conditions. ${ }^{55}$ This increases bulk density and penetration resistance, decreasing soil porosity and infiltration rates. ${ }^{56}$

51 ibid; "Cows Invade Akure Airport Runway, Delay Plane's Landing" (Core TV News, 18 February 2018) < http://coretvnews.com/cows-invade-akure-airportrunway-delay-planes-landing/> accessed on 28 February 2018.

52 In Mongolia, where a few years ago there were pastures and patches of cropland it was reported that only sandy fields remain. Also in Brazil, environmental groups have warned for years that cattle production is consuming huge chunks of the rainforest which is regarded as the largest in the world. See Ronnie Vernooy, "How Mongolian Herders Are Transforming Nomadic Pastoralism" (2011) 2 The Solutions Journal 82.

53 Ogri (n 46) 140.

54 See Asadu (n 38). It is unfortunate that soil has not received the same degree of attention as other natural resources, yet soil degradation is a threat to biodiversity, human existence, and food security. For more of the impact of soil degradation, see Temitope E Alori and Chinenye Nwapi, "The International Legal Regime for Sustainable Soil" in Rhuks T Ako and Damilola S Olawuyi (eds) Food and Agricultural Law (Afe Babalola University Press 2015) 102.

55 Agnieszka E Latawiec and others, "Intensification of Cattle Ranching Production Systems: Socioeconomic and Environmental Synergies and Risks in Brazil" (2014) 8 Animal 1255, 1257.

56 ibid. 


\section{PAST AND CURRENT EFFORTS AT DEVELOPING A LEGAL FRAMEWORK}

The issue of sedentarization of the nomadic cattle rearing system is one which for many years has generated considerable discussion in Nigeria's government circles. ${ }^{57}$ Therefore, there have been legislative efforts geared towards addressing the concern. ${ }^{58}$

\subsection{Grazing Reserve Law, 1965}

The policy of the Nigerian government in the 1960s was centred on the establishment of grazing reserves in cattle producing areas. ${ }^{59}$ At that time, cattle rearing was carried out by herders from the North. This explains the reason why it was the Northern Regional Government that enacted the Grazing Reserves Law in 1965. By that law, the Northern Region established grazing reserves in the Northern States. ${ }^{60}$ When the Northern Region ceased to exist, the Northern States absorbed the law into their state laws. ${ }^{61}$ It is a law for the constitution, preservation and control of grazing reserves and for purposes connected with it. Section 3 of the Law provides that lands, which may be constituted as a government grazing reserve, are lands at the disposal of government or native lands and any lands in respect of which it

57 Moses O Awogbade, “Grazing Reserves in Nigeria” (1987) 23 Nomadic Peoples 19.

58 Note that apart from the legislation discussed above, the National Commission for Nomadic Education was established in 1989 by Decree 41 of 12 December 1989, now known as the Nomadic Education Act, 1989. The Act established the Commission for Nomadic Education, which will, amongst other things, establish, manage and maintain primary schools for nomadic children. Cap N20 Laws of the Federation of Nigeria (LFN) 2004. The Federal Government introduced the programme in consonance with the provisions of the then Constitution of Federal Republic of Nigeria 1979 and the National Policy on Education which requires government to provide equal educational opportunities to all Nigerians in order to ensure that nomads have an unfettered access to quality basic education. The Commission was established to implement the National Programme on Nomadic Education introduced by the Federal Government in 1986.

59 Awogbade (n 57).

60 States like Kaduna, Bauchi, Plateau, Adamawa formerly Gongola and Borno all had grazing reserves.

61 For example, Grazing Reserves Law Cap. 53 Laws of Kano State, 1991; Grazing Reserves Law, Cap. 59 Laws of Yobe State, 1994; Grazing Reserves Law, No. 4, Laws of Northern Nigeria, 1965 of Plateau State. 
appears to the minister ${ }^{62}$ that grazing on such lands should be protected or reserved. ${ }^{63}$

A close perusal of the law reveals that it does not contemplate environmental protection as one of its objectives and there are no environmental protection provisions in the law. Although section 22 of the Law states that the Governor may make regulations for certain matters in respect of the grazing reserves, there is no reference to environmental protection. ${ }^{64}$ This may be attributed to the fact that environmental considerations were not a key concern and sustainable development was relatively unknown during that period. Several Northern States have duly gazetted grazing reserves. However, it has been observed that majority of these reserves lack the relevant infrastructure, are run-down, without pasture or water, especially in the dry season. ${ }^{65}$

This law was made with the northern States as the object. However the reality today is that nomadic cattle grazing and rearing is carried out all over the country, pastoralists migrate from one part of the country to another in search of grazing land and water for the animals. ${ }^{66}$ The law is, therefore, not suited for current realities. The implication of the foregoing is that the Grazing Reserve Law, 1965, in its present state, is not fit for purpose to achieve the 21st century's overarching principle of sustainable development.

62 At that time, this referred to the Minister vested with the responsibility for animal and forest resources by the Constitution of Northern Nigeria.

63 However, before any land is constituted as a government grazing reserve, a notice should be published by the Minister in the Northern Nigeria Gazette specifying the particulars of the land, $\mathrm{s} 4$.

64 Grazing Reserve Law 1965, s 22 (a)-(g). See also s 33 Section which empowers a native authority to make similar regulations, with the approval of the Minister, s 33 (a)-(g).

65 Bello (n 14) 131. See also The Vice-President of Nigeria Prof. Yemi Osinbajo's speech at the National Security Summit at the NAF Conference center and Suites, Abuja on Thursday, 8 February 2018.

66 Aderinoye-Abdulwahab (n 20). See also Abdurrahman Umar, "The Teacher Education Curriculum and the World of Work: A Study of Teachers of Disadvantaged Children in Nigeria" (2006) 22 Teacher and Teacher Education 777. 


\subsection{The National Environmental (Watershed, Mountainous, Hilly and Catchment Areas) Regulations, 2009}

This is a Regulation made pursuant to the National Environmental Standards and Regulation Enforcement Agency Act, 2007. As the title indicates, the objective is to regulate the manner in which land owners or occupiers utilize land in watershed, mountainous, hilly or catchment areas. ${ }^{67}$ With respect to these protected areas, the Agency is vested with the responsibility to control activities which are inconsistent with good land management practices. ${ }^{68}$ The Agency, in conjunction with state and local governments, are to identify these watersheds, mountainous, hilly and catchment areas within each State jurisdiction and indicate those that are at risk of degradation. ${ }^{69}$ Such areas are deemed to be at risk of environmental degradation if, among other activities, there is overgrazing. ${ }^{70}$

The Agency in collaboration with state and local governments are to collate the data of these protected areas for the purpose of maintaining a national database. ${ }^{71}$ Any individual who desires to graze livestock in these areas is expected to submit an application endorsed by the Chairman of the Local Government Area to the Agency, and the Agency may grant the permit after due consideration of the application. ${ }^{72}$ Item 5 (4)(a) of the Regulation states that the local government in conjunction with the state government and the Agency shall designate areas to be reserved for grazing and any other activities necessary to conserve the resources of areas, threatened by degradation. Regulation 9 further states that the Agency in collaboration with the State shall restrict grazing in such watersheds, mountainous, hilly and catchment areas that are identified as threatened by environmental degradation and that these authorities may issue an order prescribing the maximum number of animals that may graze or be permitted to graze on any particular area of land. ${ }^{73}$ The penalty for the contravention of any of

67 The National Environmental (Watershed, Mountainous, Hilly and Catchment Areas) Regulations 2009, Reg 1.

68 ibid Reg 1(2).

69 ibid Reg 2 (1).

70 ibid Reg 2(2)(iv).

71 ibid Reg 2(3).

72 ibid Reg 4.

73 ibid Reg 9 (1) and (2). 
these provisions may attract permit revocation, liability upon conviction to imprisonment of not more than one year or to a fine of not more than $\mathrm{N} 200,000$ or both. ${ }^{74}$ Where the offence is committed by a corporate body, it shall be liable to a fine not exceeding N1 million and an additional fine of N50,000 for every day the offence subsists. ${ }^{75}$

As laudable as these provisions are with respect to the protection of the environment, one wonders whether or not the reservation and prohibition of certain areas for grazing takes into consideration already existing grazing reserves. Even though the Regulation targets specific areas of the environment, it is not explicit if the Agency and the state and local governments are meant to create grazing reserves in addition to those created by the Grazing Reserve Law 1965, particularly with reference to Regulation 5 that requires these authorities to reserve some areas for grazing. Neither is it clear what NESREA's role ought to be in the management of such areas reserved for grazing and in the management of the existing grazing reserves in the northern states since there is no federal legislation on grazing.

On a visit to NESREA office on 20 March 2018, NESREA officials said that the mapping out of the designated areas and collation of database is ongoing. ${ }^{76}$ Consequently, the Regulation cannot be implemented as no area has been designated as a watershed, mountainous, hilly and catchment areas. The penalty provisions are, therefore, redundant. The failure in the implementation of this Regulation automatically renders it inadequate and incapable of preventing environmental degradation arising from cattle grazing.

The federal and state governments have put some machinery in motion to address the perennial and increased incidents of farmers/ herders' clashes in Nigeria. We examine them below.

\subsection{Governmental Policy}

The most recent government policy document on agriculture is the "Nigeria's Agriculture Promotion Policy 2016-2020" (The Green Alternative). ${ }^{77}$ The Policy is founded on the several guiding principles

74 The National Environmental (Watershed, Mountainous, Hilly and Catchment Areas) Regulations 2009, Reg 1, Reg 10(1)(a) and (b).

75 ibid Reg 10(3).

76 It appears that prior to this ongoing exercise, no national database of these protected areas has been compiled since the coming into effect of the Regulation.

77 "The Green Alternative" (Federal Ministry of Agriculture and Rural Development) <https://fmard.gov.ng/the-green-alternative/> accessed 6 April 2018. 
such as agriculture as business; agriculture as key to long-term economic growth and security; food as a human right; factoring climate change and environmental sustainability; and participation and inclusiveness. ${ }^{78}$ It is instructive that the principle on climate change and environmental sustainability aims to focus "... policy instruments on the sustainability of the use of natural resources (land and soil, water and ecosystems) with the future generation in mind while increasing agricultural production, marketing and other human activities in the agricultural sector." 79 The policy aims to place emphasis on providing a conducive legislative and agricultural knowledge framework, macro policies, security enhancing physical infrastructure and institutional mechanisms for coordination and enhancing access to adequate inputs, ûnance, information on innovation, agricultural services and markets.

Apart from this policy document, there is no specific policy document on cattle grazing in Nigeria. There is, however, a department of Animal Production and Husbandry Services (DAPHS) housed in the Ministry of Environment with the mandate, among other things, to grow the country's animal resources through improvement of grazing reserves, development of stock routes, and to provide pastoral services, establish grazing reserves and stock routes development.

\subsection{Laws Promulgated by State Governments}

Some State Governments such as Taraba, Benue and Ekiti have gone ahead to promulgate anti-grazing laws to curb the activities of the nomadic pastoralists. The laws are similar with little variations that take care of the peculiarities of the States. We will examine the Benue State law for the purposes of this article because of the interest and opposition it has generated. ${ }^{80}$ The Benue State government promulgated the Open Grazing Prohibition and Ranches Establishment Law, 2017. It is a law to prohibit open rearing and grazing of livestock and provide for the establishment of ranches and livestock administration, regulation and control. One of the interesting objectives of the law is the protection of the environment from degradation and pollution

78 ibid.

79 ibid.

80 The information provided by the Taraba State Ministry of Justice is that the implementation of the anti-open grazing law has been suspended for reasons the officials did not disclose.

81 Open Grazing Prohibition and Ranches Establishment Law 2017, s 3(c). 
caused by open rearing and overgrazing by livestock. ${ }^{81}$ Section 6 (4) also provides for the conduct of an Environmental Impact Assessment of the land to be used for ranching. Section 19 (1) of the Law prohibits "...open nomadic livestock herding or grazing in the State outside the permitted ranches". A violator of this provision will be guilty of an offence and shall, on conviction, be liable to five years' imprisonment or N1million fine or both. Section 19(4) prohibits movement of livestock on foot from one destination to another in the State.

Obviously, there is ample justification for the law and the environmental considerations integrated into it. However, some of the provisions appear too stringent to encourage compliance of the nomadic pastoralists, and this is capable of undermining the environmental and general objectives of the law. The ranching method the law stipulates that the pastoralists should adopt requires them to be highly trained and educated on this modern mode of cattle rearing. Meanwhile, a large percentage of the nomadic pastoralists are illiterate. ${ }^{82}$ Besides, the nomadic pastoralists are used to the traditional mode of cattle rearing, switching to a new form of cattle rearing suddenly without putting in place appropriate mechanisms appears inequitable. Ranching requires the pastoralist to confine his livestock within a fenced area designated as a ranch. The implication is that he is prohibited from moving his livestock out of the ranch. Apart from the financial requirement and highly technical nature of this mode of pastoralism, such confinement of cattle is not in consonance with the culture of the nomadic pastoralists. The nomadic pastoralists consider their trade as their culture and way of life. Already, in Nigeria, the Miyetti Allah Kautal Hore Fulani socio-cultural group is protesting this law and has stated that the Open Grazing Prohibition law of Benue state is fundamentally against their culture as nomadic pastoralists and against their economic interest. ${ }^{83}$ The group stated further that the law is unconstitutional as same restricts their movement which they say violates their freedom of movement as enshrined in the Constitution of the Federal Republic of Nigeria, 1999 (as amended). ${ }^{84}$ This has resulted in the Miyetti Allah

82 Ameh C Godwin, "Why We Won't Accept Ranching in Nigeria - Fulani Herdsmen" Daily Post (20 November 2017); The Minister of Agriculture, Audu Ogbeh, spoke about the fact that the pastoralists are ignorant of many germane issues relating to the problem of open grazing during an interview on a current affairs program on Channels Television, "Dateline Abuja" on 24 March 2018.

83 Godwin (n 82).

84 Jimoh (n 34). See section 41(1) of the 1999 Constitution states that "Every 
Kautal Hore Fulani socio-cultural group instituting an action against the Benue State government among others, in the Federal High Court, Abuja. ${ }^{85}$

Furthermore, representatives of the nomadic pastoralists ${ }^{86}$ were not invited to participate in discussions leading up to the promulgation of the Open Grazing Prohibition Law. ${ }^{87}$ One of the fallouts of nonconsultation is that the Miyetti Allah cattle breeders have complained that their breed of cattle, geographical location and the weather condition in Nigeria are not suitable for ranching. ${ }^{88}$ They stated further that in other countries where ranching is being successfully practised, the volume of rainfall is between four to seven months in a year, implying that rainfall in Nigeria is for shorter periods. ${ }^{89}$ Additionally, right from previous years, grazing land and stock routes top the list of nomadic pastoralists' demands from the government. ${ }^{90}$

citizen of Nigeria is entitled to move freely throughout Nigeria and to reside in any part thereof...". See Constitution of the Federal Republic of Nigeria 1999 <http://www.nigeria-law.org/ConstitutionOfTheFederalRepublic OfNigeria.htm $>$ accessed 19 June 2018. (Constitution of Nigeria)

85 The incorporated trustees of Miyetti Allah Kautal Hore Socio-Cultural Association \& 2 Ors $v$ The National Assembly \& 13 Ors, Suit No. FHC/ABJ/CS/527/2017. The Benue State government is the 5 th defendant in the Suit and same is still pending at the Federal High Court Abuja.

86 Such as the Confederation of Traditional Herder Organisations (CORET). See Food and Agriculture Organization of the United States, "Pastoralist Knowledge Hub" (FAO) < http://www.fao.org/pastoralist-knowledge-hub/pastoralistnetworks/database-of-organization/details/en/c/980011/> accessed 6 April 2018.

87 Rejecting calls by the Miyetti Allah Cattle Breeders' Association for the amendment of the law to accommodate their wishes, Governor Ortom, among other things, stated that the law “...was popularly made by Benue people and it has come to stay". Samson Toromade, "Ortom Vows to Keep Anti-Open Grazing Law Despite Herdsmen Threat"(Pulse NG, 12 January 2018) < http:// www.pulse.ng/news/local/ortom-vows-to-keep-anti-open-grazing-lawid7837835.html > accessed 25 March 2018.

88 Jimoh (n 34); The president of the Miyetti Allah Kautal Hore Fulani SocioCultural Group, Abdullahi Bello Bodejo, stated that right from the 70s, the old Gongola, Kaduna and old Plateau States experimented ranching but it failed because of the geographical location of Nigeria which is not suitable for ranching. 89 ibid.

90 Iro (n 14). 


\section{LEGAL PATHWAYS TO SUSTAINABILITY}

Extant legal framework on grazing in Nigeria fails to accommodate developmental and environmental challenges, such as access to land and natural resources and climate change. Evidently, the ongoing conflicts between pastoralists and farmers distort development efforts, raise security and related socio-economic issues, aggravate environmental challenges and ultimately threaten the attainment of several of the SDGs. Consequently, an effective legal and regulatory framework for cattle grazing and rearing with positive implications for environmental protection is imperative. An effective grazing law must address the following pivotal elements:

\subsection{Legal Framework}

\subsubsection{Grazing Reserve or Ranching}

There is no doubt that in the long run, ranching is a more sustainable form of rearing technique but a sudden switch as is being canvassed by the federal and state governments is not advisable. Open grazing and nomadic cattle rearing is the practice known to nomadic pastoralists for centuries, so in requiring this transition to ranching, this fact ought to be considered in any legal framework going forward. We are therefore of the opinion that there should be a gradual transition to ranching. We advocate for the establishment of cattle grazing reserves in the first instance for a period of time determinable by all stakeholders, while the pastoralists are being prepared to adopt the ranching method of cattle rearing. The resolutions arising from discussions in this regard should be included in the Federal government's policy on livestock management and in the State laws. Such laws should also designate mutually agreed routes for the grazing reserves including designated routes for the transhumant pastoralists as they enter the country.

\subsubsection{Public Participation}

Public participation in law and policy making cannot be overemphasized. Participation of stakeholders in developing any law is key to the successful implementation of, and compliance with, that law. The pros and cons of the concerns of such stakeholders ought to be considered in formulating a legal framework. It is, therefore, imperative that the state governments organize an all-inclusive meeting in order to ensure that all stakeholders, including the nomadic pastoralists, voice their concerns. 


\subsection{Institutional Framework}

\subsubsection{Co-operative Regulation amongst Relevant Agencies}

Although there is need for an institutional framework to implement the policy and laws developed to regulate cattle grazing and rearing, we do not support the call for the establishment of a new Livestock and Fisheries Ministry as being agitated by the nomadic pastoralists. ${ }^{91}$ The Federal Ministry of Agriculture already has a similar department including the State Ministries of Agriculture. These Livestock Departments at the federal and state levels can work together to oversee the implementation of the relevant policies and laws. Additionally, both the federal and state governments should work together with NESREA and the State Environmental Protection Agencies in creating the grazing reserves and eventually, the ranches to ensure that existing environmental legislation are complied with. The State Environmental Protection Agencies should, in conjunction with the State Livestock Departments, set up an inspection and monitoring mechanism that will ensure compliance of the laws by the nomadic pastoralists both at the grazing reserve and ranching stages.

\subsubsection{Effective Implementation of ECOWAS Treaty}

The country needs to implement the provisions of the ECOWAS protocol that requires transhumant herders to obtain the International Transhumance Certificate (ITC). Furthermore, it is important for policy makers and legislative draftsmen to make provisions for transhumant pastoralists in their legal framework especially looking ahead to when the ranching system will commence. For example, the land tenure requirement for indigenous pastoralists may not be the same for the foreign pastoralists since they are usually on transit and would return to their country. This can only be possible by ensuring proper documentation of foreign herders as provided for by the ECOWAS protocol.

\section{CONCLUSION}

Cattle grazing and rearing, as is being practised currently in Nigeria, is not environmentally sustainable. Several gaps relating to lack of robust

91 Ameh (n 82). 
mechanism for stakeholder participation in land reform processes, limited access to information, lack of robust legal protection for pastoralists in existing in their legal framework and inadequate access to effective dispute resolution mechanisms in case of conflict, have all exacerbated the spate of land grazing conflicts and disputes in Nigeria.

Consequently, a robust legal and regulatory framework is imperative to regulate the growth of nomadic pastoralism as another source of environmental pollution and degradation. Given the political nature of discussions on land reforms to accommodate grazing in Nigeria, a reform process will face several logistical challenges relating to public support for reforms and political will of the ruling class to push through the above discussed reforms. However, these challenges do not call for intellectual surrender. The task of reforming Nigeria's extant grazing laws, to make them more sustainable, must be understood and communicated to all stakeholders as a vital and important process that, if effectively undertaken, could usher in an era of robust environmental protection in several ecologically troubled states and regions in Nigeria. 